\title{
Propane Fuel Cells: Selectivity for Partial or Complete Reaction
}

\author{
Shadi Vafaeyan, ${ }^{1,2}$ Alain St-Amant, ${ }^{3}$ and Marten Ternan ${ }^{4}$ \\ ${ }^{1}$ Chemical and Biological Engineering, University of Ottawa, Ottawa, ON, Canada K1N 6N5 \\ ${ }^{2}$ Centre for Catalysis Research and Innovation, University of Ottawa, Ottawa, ON, Canada K1N 6N5 \\ ${ }^{3}$ Chemistry, University of Ottawa, Ottawa, ON, Canada K1N 6N5 \\ ${ }^{4}$ EnPross Inc., 147 Banning Road, Ottawa, ON, Canada K2L 1C5
}

Correspondence should be addressed to Marten Ternan; ternan@bell.net

Received 22 April 2013; Accepted 24 October 2013; Published 20 January 2014

Academic Editors: F. Chen, P. Holtappels, C. Sequeira, and Z. Zhan

Copyright (C) 2014 Shadi Vafaeyan et al. This is an open access article distributed under the Creative Commons Attribution License, which permits unrestricted use, distribution, and reproduction in any medium, provided the original work is properly cited.

\begin{abstract}
The use of propane fuel in high temperature $\left(120^{\circ} \mathrm{C}\right)$ polymer electrolyte membrane $(\mathrm{PEM})$ fuel cells that do not require a platinum group metal catalyst is being investigated in our laboratory. Density functional theory (DFT) was used to determine propane adsorption energies, desorption energies, and transition state energies for both dehydrogenation and hydroxylation reactions on a $\mathrm{Ni}(100)$ anode catalyst surface. The Boltzmann factor for the hydroxylation of a propyl species to form propanol and its subsequent desorption was compared to that for the dehydrogenation of a propyl species. The large ratio of the respective Boltzmann factors indicated that the formation of a completely reacted product (carbon dioxide) is much more likely than the formation of partially reacted products (alcohols, aldehydes, carboxylic acids, and carbon monoxide). That finding is evidence for the major proportion of the chemical energy of the propane fuel being converted to either electrical or thermal energy in the fuel cell rather than remaining unused when partially reacted species are formed.
\end{abstract}

\section{Introduction}

Fuel cells convert the chemical energy of a fuel into electrical energy. Theoretically they can produce more electrical energy from a fuel than either batteries or combustion processes. Propane was the fuel investigated for the fuel cells described in this work. Trucks currently deliver liquefied petroleum gas (LPG) (mostly propane) in rural areas where roads exist. The cost of delivering conventional electrical power in rural areas is approximately an order of magnitude greater than that in urban areas, even though the price charged by utility companies for electrical power is often similar. Therefore, a greater capital cost for fuel cells can be accepted in rural areas than in urban areas. This indicates that a niche market for propane fuel cells in rural areas would be profitable prior to a profitable market in urban areas.

Most fuel cells use either hydrogen or methanol as the fuel. They have several disadvantages. Unfortunately no infrastructure exists for their distribution and storage. Furthermore they are both manufactured from natural gas (primarily methane) using complex reactor systems that have a large capital cost. They also have a large operating cost because $25 \%$ of the natural gas is consumed to provide the endothermic heat for the steam reforming reaction. Hydrogen gas requires sophisticated storage systems [1]. None of those disadvantages occur when propane reacts directly at the anode of a fuel cell.

The type of propane fuel cell we are investigating is a high temperature polymer electrolyte membrane (PEM) fuel cell operating near $120^{\circ} \mathrm{C}$. It has several advantages over conventional PEM fuel cells that operate near $80^{\circ} \mathrm{C}$. The principal one is the elimination of liquid phase water, which eliminates the accumulation of acidic species and the resulting corrosion. With a less corrosive environment, the platinum group metals used as catalysts in conventional PEM fuel cells can be replaced by less expensive metals such as nickel (at the anode) and silver (at the cathode). Unfortunately the proton conductivity of the Nafion electrolyte used in conventional PEM fuel cells diminishes by an order of magnitude when the operating temperature increases from 80 to $120^{\circ} \mathrm{C}$. To circumvent this difficulty we have begun an experimental program on the development of a modified zirconium phosphate, $\mathrm{ZrP}$, 
membrane that appears to be suitable for $120^{\circ} \mathrm{C}$ operation (AlOthman et al. [2, 3]).

The primary challenge with fuel cells that use propane and other hydrocarbons as their fuel is that the current densities (reaction rates) are small. During the 1960s an extensive amount of research on direct hydrocarbon fuel cells (DHFCs) including propane fuel cells was performed [4-6]. Since that time, there have been relatively few experimental investigations. They include hydrocarbons being fed to the anode of solid oxide fuel cells [7] operations at $300^{\circ} \mathrm{C}$ using $1 \mathrm{~mm}$ thick $\mathrm{Sn}_{0.9} \mathrm{In}_{0.1} \mathrm{P}_{2} \mathrm{O}_{7}[8]$, kinetics and mechanisms [9-11], and the use of polymer electrolytes [12-14].

Fuel cell reactions can be examined at different levels of detail. The overall propane reaction in a propane high temperature PEM fuel cell is shown as

$$
\mathrm{C}_{3} \mathrm{H}_{8}(\mathrm{~g})+5 \mathrm{O}_{2}(\mathrm{~g})=3 \mathrm{CO}_{2}(\mathrm{~g})+4 \mathrm{H}_{2} \mathrm{O}(\mathrm{g}) \text {. }
$$

The overall half-cell reaction for a propane fuel cell anode is shown as

$$
\mathrm{C}_{3} \mathrm{H}_{8}(\mathrm{~g})+6 \mathrm{H}_{2} \mathrm{O}(\mathrm{g})=3 \mathrm{CO}_{2}(\mathrm{~g})+20 \mathrm{H}^{+}(\mathrm{ZrP})+20 \mathrm{e}^{-}(\mathrm{Ni}),
$$

where $(\mathrm{g})$ is gas phase, $(\mathrm{ZrP})$ is $\mathrm{Zr}\left(\mathrm{HPO}_{4}\right)_{2} \cdot \mathrm{H}_{2} \mathrm{O}$-glycerol electrolyte, and $(\mathrm{Ni})$ is nickel metal anode electrocatalyst. Nickel was chosen for the anode electrocatalyst, because it was known to be an effective nonplatinum catalyst in alkaline fuel cells [15]. The mechanism by which the propane reaction in (2) is expected to occur is shown in Figure 1. The reaction mechanism in Figure 1 is analogous to the reaction mechanism for methane that was reported by Bagotzky et al. [16]. Propane in the gas phase is first adsorbed on the nickel metal electrocatalyst. Then it is dehydrogenated to form an adsorbed propyl species. The investigation reported here primarily concerns the subsequent reactions of the adsorbed propyl species. It could react with a hydroxyl group to form propanol (an alcohol), $\mathrm{C}_{3} \mathrm{H}_{7} \mathrm{OH}(\mathrm{Ni})$, followed by desorption to the gas phase. Alternatively a hydrogen atom could be removed to form an adsorbed allyl species, $\mathrm{C}_{3} \mathrm{H}_{6}(\mathrm{Ni})$. An appropriate combination of subsequent dehydrogenation and hydroxylation reactions could lead to complete reaction and the formation of $\mathrm{CO}_{2}$. At the anode there is only one electrochemical reaction, $\mathrm{H}^{--}>\mathrm{H}^{+}+\mathrm{e}^{-}$. Figure 1 shows that the majority of the elementary fuel cell reactions on a propane fuel cell nickel anode electrocatalyst do not involve charge transfer.

The general purpose of this work was to investigate the reactions in the network shown in Figure 1. One specific objective was to determine whether or not the hydrocarbon reaction intermediates remain on the catalyst surface where a series of dehydrogenation reactions can combine with hydroxylation reactions to ultimately form carbon dioxide, the completely reacted product. The undesirable alternative would be for the hydrocarbon surface species to retain their hydrogen atoms and to form partially reacted products such as alcohols, aldehydes, and carboxylic acids. For fuel cells complete reaction is desired since some of the fuel's chemical energy remains unused when partially reacted products are formed.

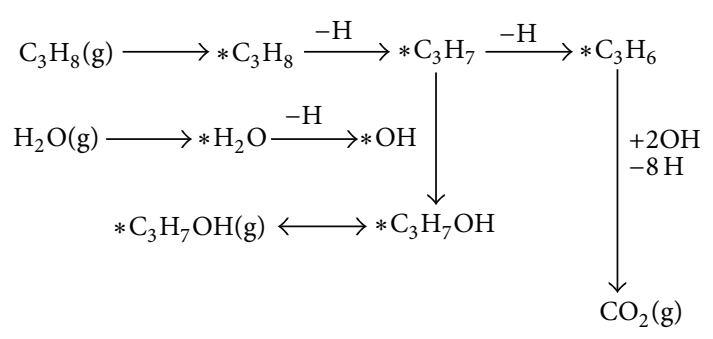

Figure 1: A partial electrochemical reaction network for propane.

Catalyst composition appears to be the factor that determines if the products are partially reacted or completely reacted. Several experiments with a platinum anode have shown that $\mathrm{CO}_{2}$ was the predominant product formed in specific situations. The only product reported was $\mathrm{CO}_{2}$ when the hydrocarbon fuel was (a) ethylene being fed to a sulphuric acid fuel cell [17], (b) propane being fed to a phosphoric acid fuel cell [18], and (c) methane being fed to a PEMFC [19]. When a PEMFC with a platinum anode was being fed propane, the major product was $\mathrm{CO}_{2}$ at cell potentials less than $0.1 \mathrm{~V}$ and $\mathrm{CO}$ when the cell potential was greater than $0.4 \mathrm{~V}$ [20]. In contrast with a platinum-ruthenium anode, when methane was being fed to a PEMFC, all of the possible partial reaction products, $\mathrm{CH}_{3} \mathrm{OH}, \mathrm{CH}_{2} \mathrm{O}, \mathrm{COOH}, \mathrm{CO}$, and $\mathrm{CO}_{2}$, were formed [19]. This work was performed to obtain an indication of whether complete or partial reaction products would be obtained when using a nickel catalyst.

\section{Methodology and Computational Details}

SIESTA software based on Kohn-Sham density functional theory was used to perform quantum chemical computations (Soler et al. [21]). The generalized gradient approximation (GGA) method was used as the exchange correlation functional type, with Becke, Lee, Yang, and Parr (BLYP) parameterization. The default basis set, a double- $\zeta$ polarization set composed of a compact and a diffused orbital basis, was used in these calculations. The tolerance of the density matrix was set to $10^{-3}$. This value sets the maximum allowable difference between the output and the input on each element of the density matrix in a self-consistent field (SCF) cycle. A $4 \times$ $4 \times 4(4 * 4 * 4 / 2=32 k$-points $)$ Monkhorst-Pack $k$-point mesh was used. The convergence as a function of the number of $k$-points was carefully monitored. Increasing the $k$-point mesh from $32 k$-points to $48 k$-points changed the adsorption energies by an insignificant amount $\left(\sim 4 \times 10^{-5} \mathrm{eV}\right.$ or $\sim 8 \times$ $10^{-3} \mathrm{~kJ} / \mathrm{mol}$ ). In some calculations, the coordinates of atoms were allowed to relax (change position) to determine the geometry having the minimum energy. When the difference in energy between successive calculations was less than $10^{-3} \mathrm{eV}$ and when the maximum atomic force was less than $0.01 \mathrm{eV} / \AA$, the convergence criteria were attained and the atomic geometry was optimized.

The pseudopotential for nickel was generated using the ATOM program of SIESTA. The Perdew Burke Ernzerhof (PBE) [22] exchange correlation was used for the generation 
of the electronic configuration. The improved TroullierMartins (tm2) method was used to generate the pseudopotential file for nickel in its nonpolarized ground state electron configuration. The pseudopotential input file for a metal required that a particular core radius, $r_{c}$, should be specified. It was obtained by trial and error. If the initial $r_{c}$ value was too small ( $\leq 1.5$ for metals used in this study), the pseudopotential could not be generated. After a value of $r_{c}$ that was slightly greater than the minimum acceptable value had been obtained, the software would generate an exact value for $r_{c}$. That $r_{c}$ value (3.34 bohr for nickel) was used to generate the pseudopotential. The pseudopotential output file was used for all subsequent computations that included nickel atoms. To confirm the validity of our pseudopotential generation method and the resulting pseudopotentials, energy calculations were performed for a Ni unit cell using our custom generated Ni pseudopotential. The lattice constant (LC) that had the minimum total energy for the Ni unit cell was $0.370 \mathrm{~nm}$. There is a difference of $4.9 \%$ when the $3.70 \mathrm{~nm}$ value is compared to the experimental LC for $\mathrm{Ni}(0.352 \mathrm{~nm})$ that was measured by X-ray diffraction (XRD; Haynes [23]). This error is smaller than the $6 \%$ error that was reported when using the PBE functional (Perdew et al. [24]).

DFT calculations were performed on a system of periodically repeated entities, defined in relation to nickel crystal unit cells. Each entity consisted of one propane molecule, a slab of nickel atoms, and a vacuum space. The slab consisted of one layer of crystal unit cells (two layers of $\mathrm{Ni}$ atoms) located on an $x-y$ plane. The cells were arranged 3 cells $\times 3$ cells with 4 atoms per cell $(3 \times 3 \times 4=36$ atoms per slab). The (100) surface was used for all nickel slabs. The vacuum space had a thickness of nine empty unit cells and was located above the nickel slab in the $z$ direction. The vacuum space occupied the distance from the upper surface of a nickel slab within one periodic entity to the bottom surface of the next nickel slab above it in the next periodic entity. Ideally the vacuum layer can prevent or minimize interactions between the periodic entities in the direction perpendicular to the surface. The choice of slabs with 36 nickel atoms per slab is typical of the number of metal atoms in many DFT slab calculations [25-28].

The slab surface should be large enough, in relation to the surface species, to avoid both (a) interactions between the surface species on one slab and the nickel atoms in neighbouring slabs and (b) adsorbate-adsorbate interactions. Because there were 18 atoms in the surface of our slabs, the fractional surface coverage of propane was less than 0.2 . It has been shown by Grabow et al. [29] that adsorbate-adsorbate interactions can influence the binding energy by as much as $1 \mathrm{eV}$ when the fractional surface coverage increases from 0.2 to 1 . Our low surface coverage minimized absorbate-adsorbate contributions to the adsorption energy.

To confirm that the slabs were thick enough to predict propane adsorption on $\mathrm{Ni}(100)$ the thickness of the slabs was increased from 2 atoms to 4 atoms (increasing the number of atoms per slab from 36 to 72 ). The increased slab thickness only changed the value of the propane adsorption energy by $7.3 \%(\sim 0.04 \mathrm{eV}$ or $\sim 4 \mathrm{~kJ} / \mathrm{mol})$. This relatively small variation indicates that calculations using slabs having two layers of atoms are sufficiently accurate to qualitatively predict trends in propane adsorption energy.

Another single adsorption energy calculation for propane was performed on a 2-layer $\mathrm{Ni}(100)$ slab in which the bottom layer was fixed at the positions of bulk nickel and the top layer was allowed to relax. When compared to the calculation in which the atoms in both layers were allowed to relax, the change in energy was also very small $\left(4 \times 10^{-4} \mathrm{eV} \sim\right.$ $0.04 \mathrm{~kJ} / \mathrm{mol}$ ).

The adsorption energies $\left(E_{\mathrm{ads}}\right)$ of the adsorbates (initially adsorbed reactants and subsequent adsorbed intermediate species) on the metal slabs were calculated according to the following equation:

$$
E_{\text {ads }}=\left(E_{\text {adsorbate }+ \text { slab }}\right)_{\mathrm{MIN}}-E_{\text {species }}-E_{\text {slab }},
$$

where $E_{\text {adsorbate+slab }}$ is the total energy for the absorbate plus metal slab, $\left(E_{\text {adsorbate }+ \text { slab }}\right)_{\text {MIN }}$ is the total energy for the configuration of the adsorbate plus metal slab that has the minimum energy, $E_{\text {species }}$ is the energy of an isolated reactant molecule in the gas phase, $E_{\text {slab }}$ is the energy for a metal slab, and $E_{\text {ads }}$ is the energy for adsorption of the species on the surface of the metal slab (or heat of adsorption).

The transition state energy, $\Delta E_{\mathrm{TS}}$, for each reaction was obtained by calculating $E_{\text {adsorbate+slab }}$ as a function of either the $\mathrm{C}-\mathrm{H}$ bond length or the $\mathrm{O}-\mathrm{H}$ bond length. For each $E_{\text {adsorbate+slab }}$ calculation either the $\mathrm{C}-\mathrm{H}$ bond length or the $\mathrm{O}-\mathrm{H}$ bond length was maintained constant, while all other bond lengths and all bond angles in the adsorbed species were relaxed to obtain the adsorbate configuration having the minimum energy for that particular $\mathrm{C}-\mathrm{H}$ or $\mathrm{O}-\mathrm{H}$ bond length. Subsequently the resulting energies that had been calculated at each $\mathrm{C}-\mathrm{H}$ or $\mathrm{O}-\mathrm{H}$ bond length were compared as a function of their bond lengths. The configuration of the adsorbed species having the maximum energy, $\left(E_{\text {adsorbate+slab }}\right)_{\mathrm{MAX}}$, was the transition state (TS).

The transition state energies were obtained using the following equation:

$$
\Delta E_{\mathrm{TS}}=\left(E_{\text {adsorbate+slab }}\right)_{\mathrm{MAX}}-\left(E_{\text {adsorbate+slab }}\right)_{\mathrm{MIN}} \cdot
$$

Variations in the electrical potential of the slabs were not considered (zero electric field).

\section{Results and Discussion}

A dehydrogenation mechanism for the transformation of propane, in the gas phase, to an adsorbed propyl species is shown in Figure 2. The formula $-(\mathrm{Ni}-\mathrm{Ni}){ }_{\text {SLAB }}$ represents a 36-atom slab of $\mathrm{Ni}$ atoms in two layers in which the $\mathrm{Ni}$ atoms in each layer have fourfold symmetry. The adsorbed propane (Figure 3(a)) is oriented parallel to the Ni slab surface. That is, a plane drawn though the three carbon atoms in the adsorbed propane (Figure 3(a)) is perpendicular to the $\mathrm{Ni}(100)$ surface. The central carbon atom of the propane has on-top coordination with the nickel atom below it. Relative to the central carbon atom, the two propane end carbon atoms are symmetrical and are elevated from the slab surface. The hydrogen atoms that are bonded to the propane central 


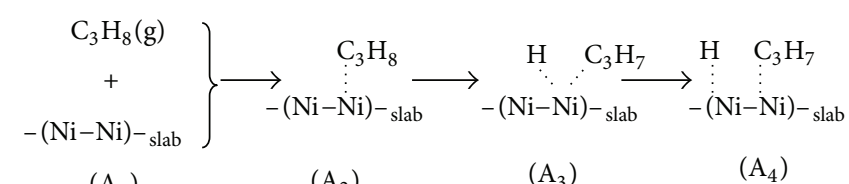

$\left(\mathrm{A}_{1}\right) \quad\left(\mathrm{A}_{2}\right) \quad\left(\mathrm{A}_{3}\right) \quad\left(\mathrm{A}_{4}\right)$

Figure 2: Propane adsorption and subsequent dehydrogenation to form a propyl species on the surface of a $\mathrm{Ni}(100)$ slab $\left(A_{1}, A_{2}, A_{3}\right.$, and $A_{4}$ identify the various entities).

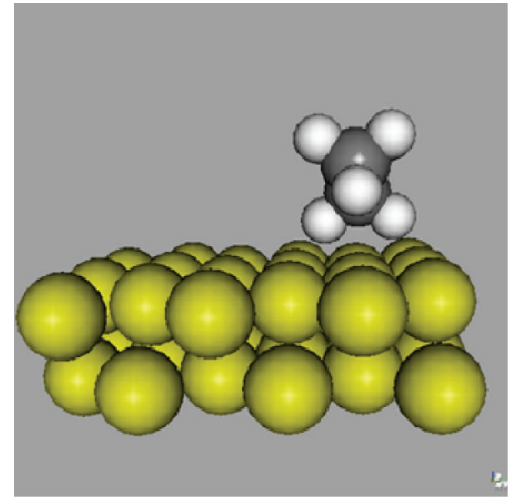

(a)

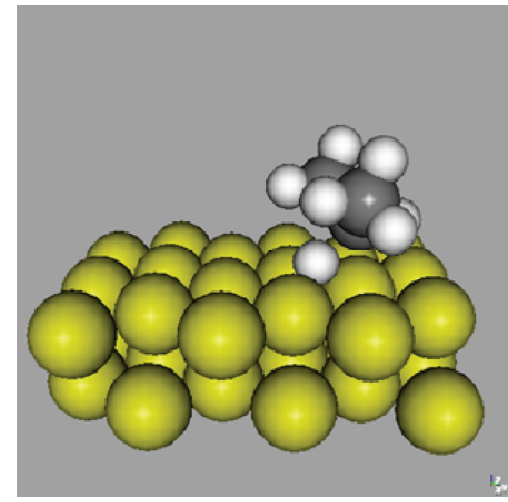

(b)

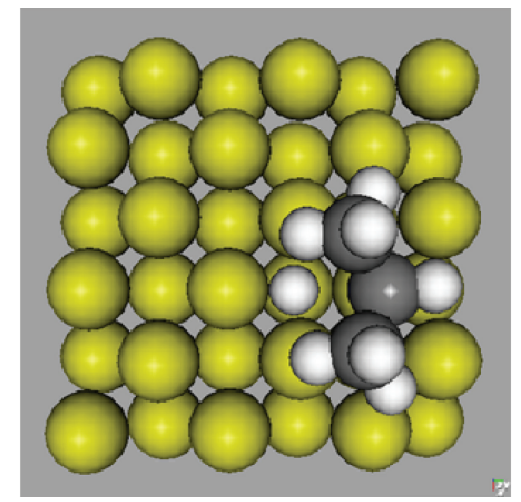

(c)

FIGURE 3: DFT optimized structures for (a) adsorbed $\mathrm{C}_{3} \mathrm{H}_{8}$ (front view) with $\mathrm{C}-\mathrm{H}=0.11 \mathrm{~nm}$, (b) TS of adsorbed $\mathrm{C}_{3} \mathrm{H}_{8}$ dehydrogenation to form a $\mathrm{C}_{3} \mathrm{H}_{7}$ species (front view bent) with $\mathrm{C}-\mathrm{H}=0.17 \mathrm{~nm}$, and (c) adsorbed $\mathrm{C}_{3} \mathrm{H}_{7}$ and $\mathrm{H}$ species (top view) with $\mathrm{C}-\mathrm{H}=0.26 \mathrm{~nm}$ on a Ni(100) slab.

carbon atom are also coordinated to the same $\mathrm{Ni}$ atom as the propane central carbon atom. In Figure 3 the $\mathrm{C}-\mathrm{H}$ bond distance between the central carbon atom and its hydrogen atoms is $0.110 \mathrm{~nm}$ compared to $0.112 \mathrm{~nm}$ when propane is in the gas phase.

The adsorption energy of propane on $\mathrm{Ni}, 0.534 \mathrm{eV}$ $(51.2 \mathrm{~kJ} / \mathrm{mole})$, is also shown in Figure 3 . Other computed values for propane adsorption on metals include values of 33$38 \mathrm{~kJ} / \mathrm{mol}$ on Pt, shown by Nykänen and Honkala [30], a value of $55 \mathrm{~kJ} /$ mole on Pd, shown by Antony et al. [31] and 39.8-42.1 on Pd, shown by Kao and Madix [32]. Experimental values for propane adsorption on metals include a calorimetric measurement of $32 \mathrm{~kJ} / \mathrm{mol}$ on a Mo film by Smutek and Černý [33], and temperature programmed desorption measurements on $\mathrm{Pd}$, shown of $41.5 \mathrm{~kJ} / \mathrm{mol}$, shown by $\mathrm{KaO}$ and Madix [32] and $45 \mathrm{~kJ} / \mathrm{mol}$, shown by Antony et al. [31]. Nykänen and Honkala [30] noted that there is considerable uncertainty in heat measurements made by temperature programmed desorption. Furthermore the adsorption energy on Ni would be expected to be different than those on Mo or Pd. Nevertheless, the propane adsorption energy on Ni reported here is of the same magnitude as the values obtained for other metals either by computation or by measurement.

The transition state (TS) between an adsorbed propane molecule and an adsorbed propyl species is shown in Figure 3(b). An important feature of the TS is that both the propyl species and its separated hydrogen atom remain configured to the same $\mathrm{Ni}$ atom in the slab (structure $\mathrm{A}_{3}$ in Figure 2). The TS structure is neither symmetrical nor parallel to the Ni slab surface. A plane drawn through

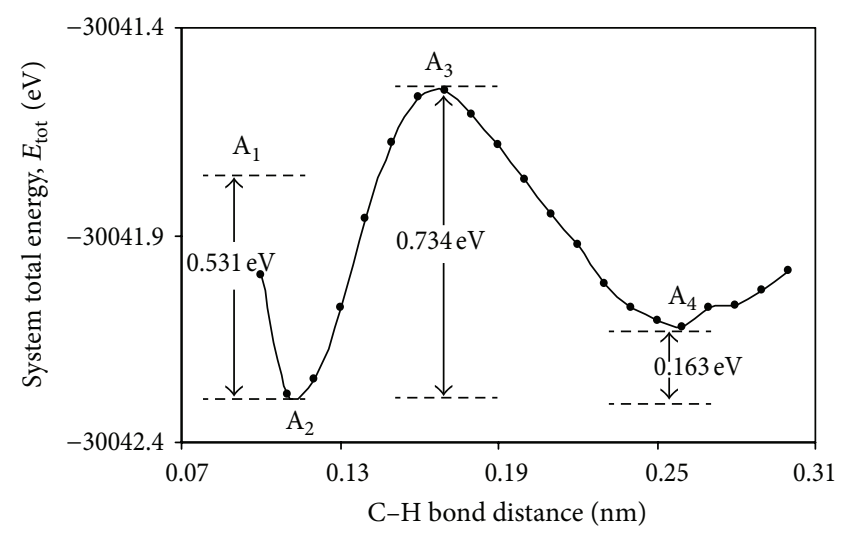

FIGURE 4: Energy plot (obtained using DFT calculated energies) for propane dehydrogenation to form propyl and hydrogen species on a $\mathrm{Ni}(100)$ slab. $\mathrm{A}_{1}, \mathrm{~A}_{2}, \mathrm{~A}_{3}$, and $\mathrm{A}_{4}$ are the entities shown in Figure 2.

the three carbon atoms of the TS structure (Figure 3(b)) intersects with the surface of the $\mathrm{Ni}(100)$ slab at an angle that is different from $90^{\circ}$. The carbon-hydrogen distance for the hydrogen being removed from the central propane carbon atom is shown at a distance of $0.170 \mathrm{~nm}$ in the TS. That is substantially larger than the $0.110 \mathrm{~nm} \mathrm{C}-\mathrm{H}$ distance in the adsorbed propane.

Figure 4 provides the energies of the four species shown in Figure 2. The extent of the dehydrogenation reaction is indicted by the $\mathrm{C}-\mathrm{H}$ bond distance between the propane central carbon atom and the hydrogen atom being removed. 


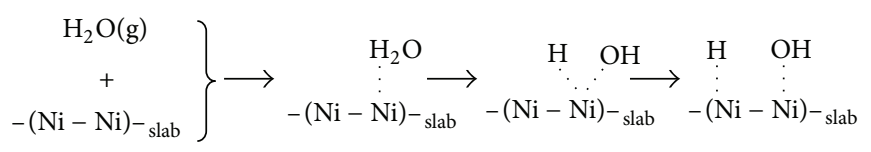

$\left(\begin{array}{lll}\left(\mathrm{B}_{1}\right) & \left(\mathrm{B}_{2}\right) & \left(\mathrm{B}_{3}\right)\end{array}\right.$

FIGURE 5: Adsorption and dissociation of water on the surface of a $\mathrm{Ni}(100)$ slab $\left(\mathrm{B}_{1}, \mathrm{~B}_{2}, \mathrm{~B}_{3}\right.$, and $\mathrm{B}_{4}$ identify the various entities).

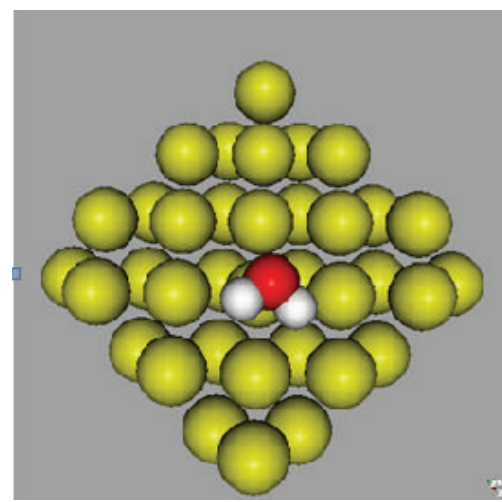

(a)

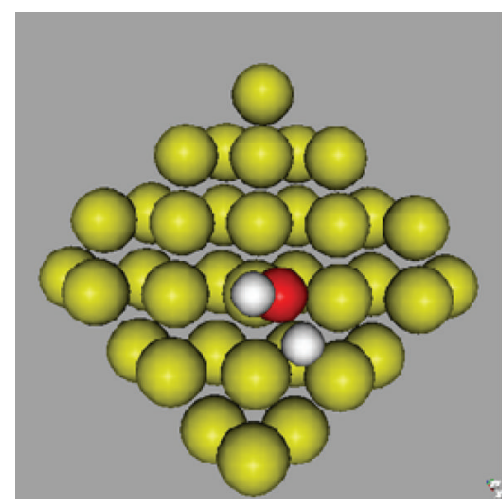

(b)

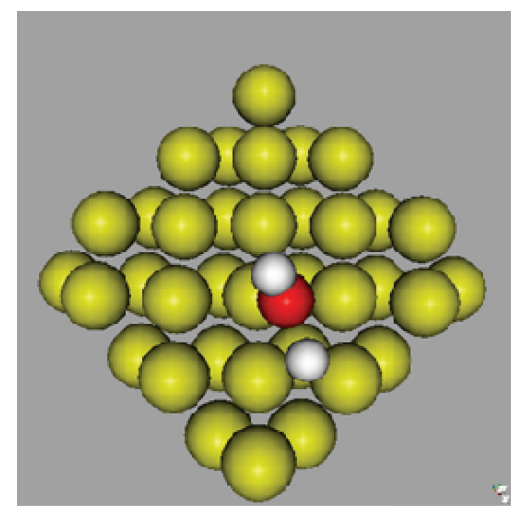

(c)

FIGURE 6: Water dissociation: top views of DFT optimized structures for (a) adsorbed $\mathrm{H}_{2} \mathrm{O}$ (initial state) with $\mathrm{O}-\mathrm{H}=0.10 \mathrm{~nm}$, (b) TS: adsorbed $\mathrm{OH}$ and $\mathrm{H}$ species with $\mathrm{O}-\mathrm{H}=0.16 \mathrm{~nm}$, and (c) dissociated $\mathrm{OH}$ and $\mathrm{H}$ species with $\mathrm{O}-\mathrm{H}=0.18 \mathrm{~nm}$ on a Ni(100) slab $(3 \times 3 \times 1 \mathrm{unit}$ cell system).

The energy change upon propane adsorption on the $\mathrm{Ni}(100)$ slab is $0.531 \mathrm{ev}(51.2 \mathrm{~kJ} / \mathrm{mole})$. The barrier height between an adsorbed propane molecule and its TS to an adsorbed propyl species is $0.734 \mathrm{eV}(70.8 \mathrm{~kJ} / \mathrm{mole})$. The energy of reaction from an adsorbed propane molecule to an adsorbed propyl species and an adsorbed hydrogen atom is $0.163 \mathrm{eV}$ $(15.7 \mathrm{~kJ} / \mathrm{mole})$. The transition state energy $\Delta E_{\mathrm{TS}}=0.734 \mathrm{eV}$ we obtained by varying the $\mathrm{C}-\mathrm{H}$ bond distance is a close approximation to the true transition state energy that would have been obtained from a saddle point calculation.

A mechanism for the dissociation of water is shown in Figure 5. The structures of the water derived adsorbed species are shown in Figure 6. The top view of an adsorbed water molecule suggests that the threefold nature of the three atoms in the water molecule (one oxygen atom and two hydrogen atoms) appears to be coordinated on top of a single $\mathrm{Ni}$ atom in the $\mathrm{Ni}(100)$ surface. The $\mathrm{O}-\mathrm{H}$ bond distance in adsorbed water, $0.100 \mathrm{~nm}$, is different than that in gas phase water, $0.145 \mathrm{~nm}$.

The transition state (TS) from adsorbed water to the combination of an adsorbed hydroxyl species and an adsorbed hydrogen atom is shown in Figure 6(b). The $\mathrm{O}-\mathrm{H}$ bond distance in the TS has increased to $0.160 \mathrm{~nm}$ which is a substantial change when compared to the $0.100 \mathrm{~nm} \mathrm{O}-\mathrm{H}$ bond distance in adsorbed water.

The energies of the four species in Figure 5 are shown in Figure 7, as a function of the dissociation reaction, as measured by the $\mathrm{O}-\mathrm{H}$ bond distance. The energy change upon water adsorption on the $\mathrm{Ni}(100)$ surface is $0.798 \mathrm{ev}$ $(77.0 \mathrm{~kJ} / \mathrm{mole})$. The barrier height between an adsorbed water molecule and its TS to an adsorbed hydroxyl radical is

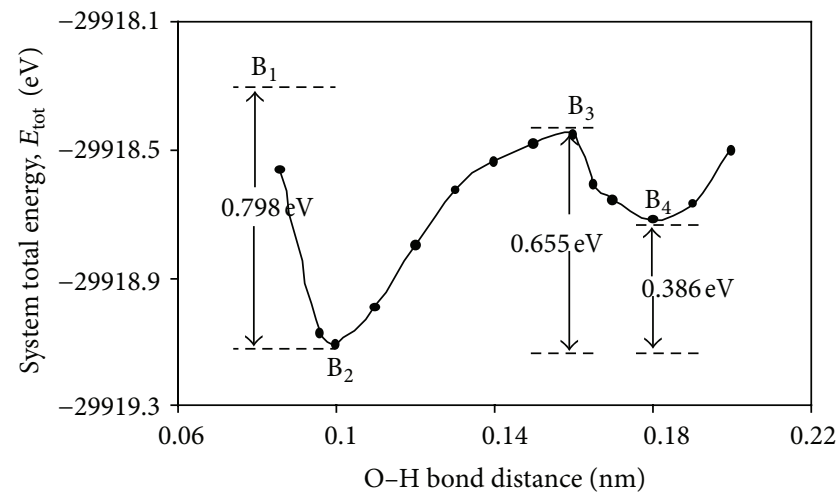

FIGURE 7: Energy plot (obtained using DFT calculated energies) for water dissociation to form hydroxyl and hydrogen species on a $\mathrm{Ni}(100)$ slab. $\mathrm{B}_{1}, \mathrm{~B}_{2}, \mathrm{~B}_{3}$, and $\mathrm{B}_{4}$ are the energy levels for the species in the reaction sequence shown in Figure 5.

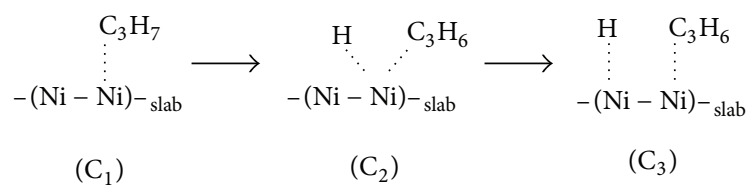

FIgURE 8: Dehydrogenation of a propyl $\left({ }^{*} \mathrm{C}_{3} \mathrm{H}_{7}\right)$ species to an allyl $\left({ }^{*} \mathrm{C}_{3} \mathrm{H}_{6}\right)$ species on the surface of a $\mathrm{Ni}(100)$ slab.

$0.655 \mathrm{eV}(63.2 \mathrm{~kJ} / \mathrm{mole})$. There are numerous reports in the literature on the dissociation of water on metals. For example, a DFT study [34] of 6 different metals, Os, Ru, P, Ir, Rh, and 


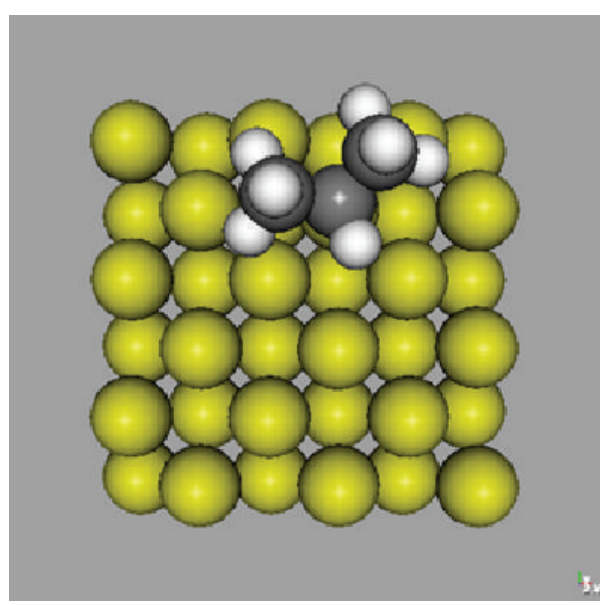

(a)

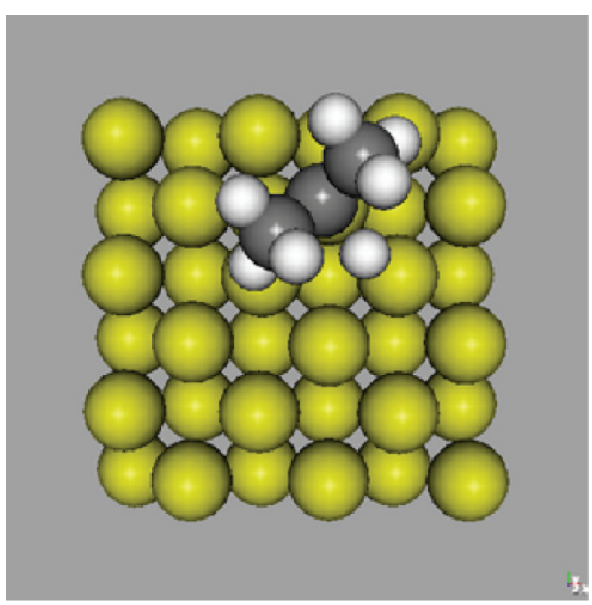

(b)

FIGURE 9: Propyl dehydrogenation (allyl radical formation): top views of DFT optimized structures for (a) initial state: adsorbed propyl $\left({ }^{*} \mathrm{C}_{3} \mathrm{H}_{7}\right)$ with $\mathrm{C}-\mathrm{H}=0.11 \mathrm{~nm}$, and (b) TS: adsorbed allyl $\left({ }^{*} \mathrm{C}_{3} \mathrm{H}_{6}\right)$ and hydrogen $\left({ }^{*} \mathrm{H}\right)$ species with $\mathrm{C}-\mathrm{H}=0.18 \mathrm{~nm}$ on a Ni $(100)$ slab $(3 \times 3 \times 1$ unit cell system).

Pt, reported barrier heights in the range of 0.343 to $1.25 \mathrm{eV}$. Another example is a study by Pozzo et al. [35] comparing the dissociation of water on $\mathrm{Rh}(111)$ and $\mathrm{Ni}(111)$ surfaces. They reported barrier heights of 0.92 and 0.89 for the water dissociation reaction to $\mathrm{OH}$ and $\mathrm{H}$ on $\mathrm{Rh}(111)$ and $\mathrm{Ni}(111)$, respectively. The energy change during reaction of an adsorbed water molecule to form an adsorbed hydroxyl species and an adsorbed hydrogen atom is $0.386 \mathrm{eV}(37.2 \mathrm{~kJ} / \mathrm{mole})$. The barrier height for the combination of formation of hydroxyl species and hydrogen atoms (Figure 7) is approximately $10 \%$ less than that for the combination of the formation of propyl species and hydrogen atoms (Figure 4). If a comparison of two different single barrier heights was the only consideration, it would suggest that it might be easier to form hydroxyl species than propyl species and that hydroxyl species might be more abundant on the $\mathrm{Ni}(100)$ surface than propyl species.

A mechanism for the second dehydrogenation reaction, conversion of adsorbed propyl species to adsorbed allyl species, is shown in Figure 8. The structures of the adsorbed propyl species and the TS from an adsorbed propyl species to an adsorbed allyl species are shown in Figure 9. The central carbon atom of the adsorbed propyl radical in Figure 9(a) is on top of one of the $\mathrm{Ni}$ atoms in the $\mathrm{Ni}(100)$ slab. A plane drawn through the three carbon atoms of the propyl species intersects the surface of the intersects the $\mathrm{Ni}(100)$ surface at an angle that is much different than $90^{\circ}$, indicating that the propyl species is not situated symmetrically on the $\mathrm{Ni}(100)$ surface.

The transition state (TS) from an adsorbed propyl species to an adsorbed allyl species is shown in Figure 9(b). The central carbon atom of the TS is on top of a Ni atom in the surface. The hydrogen atom that is being removed from the central carbon atom is bridge bonded with two Ni atoms that are adjacent to the $\mathrm{Ni}$ atom on which the allyl central carbon atom is on top. The distance between the central carbon atom in the TS and the separated hydrogen in the TS has increased

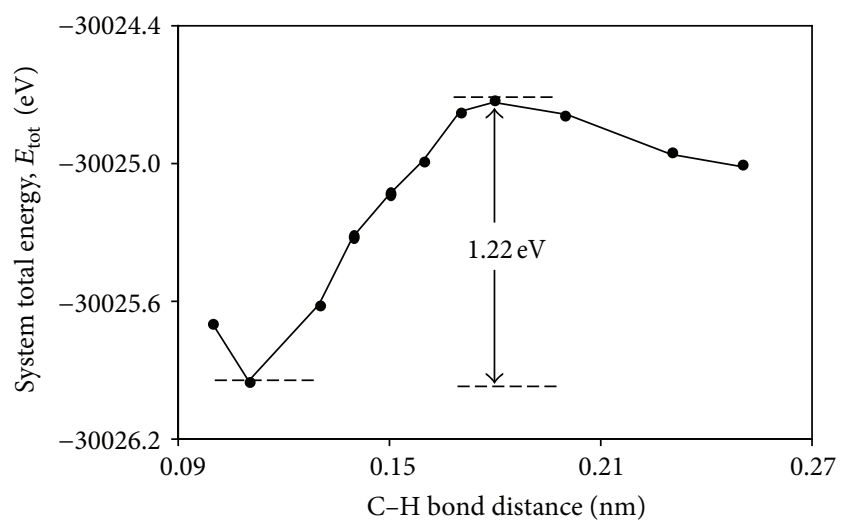

FIGURE 10: Energy plot (obtained using DFT calculated energies) for propyl dehydrogenation to form allyl and hydrogen species on a $\mathrm{Ni}(100)$ slab.

to approximately $0.180 \mathrm{~nm}$ which is a substantial change when compared to the $\mathrm{C}-\mathrm{H}$ bond distance in an adsorbed propyl species.

The energies of the three species in the transition from propyl to allyl, in Figure 8, are shown in Figure 10, as a function of the dehydrogenation reaction, as measured by the $\mathrm{C}-\mathrm{H}$ bond distance. There is a difference in energy of approximately $16 \mathrm{eV}$ between the combination of the propyl species and slab that is represented in Figures 8 and 10 and the combination of propyl radical, hydrogen radical, and slab represented in Figures 2 and 4. The barrier height between an adsorbed propyl species and the transition state (TS) to an adsorbed allyl species and a hydrogen atom, is $1.22 \mathrm{eV}$ ( $118 \mathrm{~kJ} / \mathrm{mole})$.

A mechanism for the synthesis reaction, between an adsorbed propyl species and an adsorbed hydroxyl species to form propanol, is shown in Figure 11. The structures of the adsorbed propyl and hydroxyl species are shown 


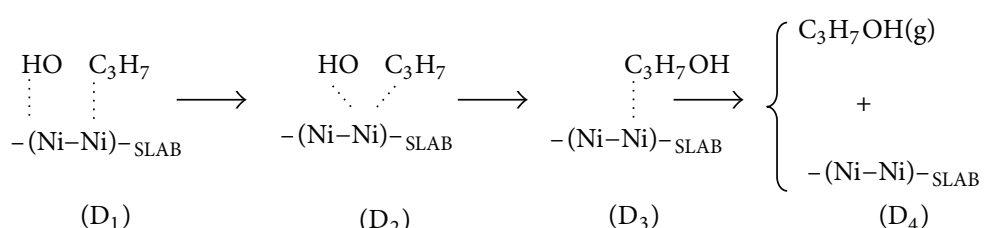

Figure 11: Formation of propanol from adsorbed hydroxyl and propyl species on the surface of a $\operatorname{Ni}(100)$ slab $\left(D_{1}, D_{2}, D_{3}\right.$, and $D_{4}$ identify the various entities).

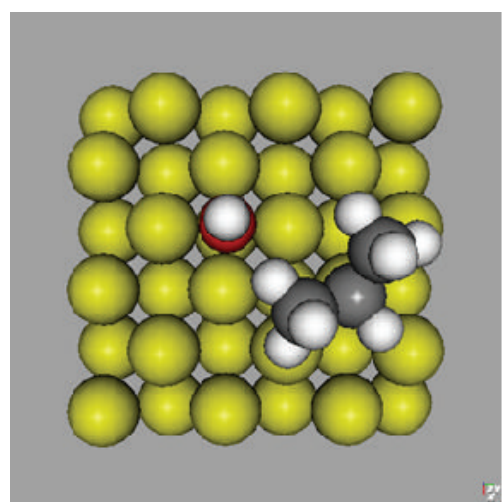

(a)

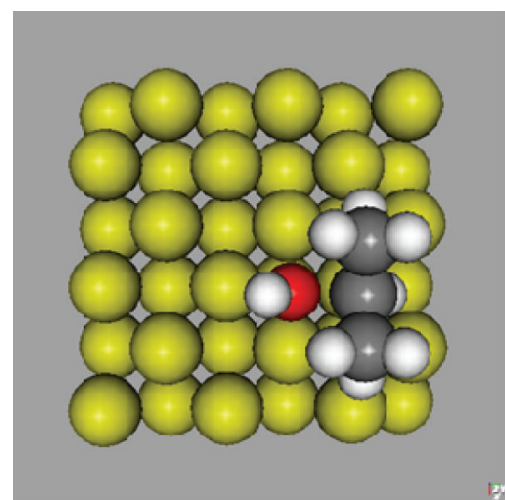

(b)

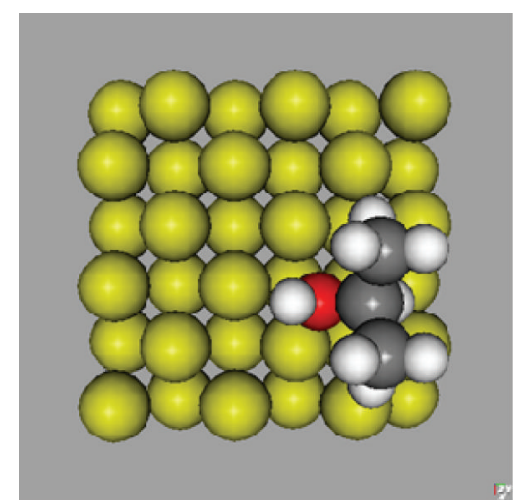

(c)

FIGURE 12: Propanol formation: top views of DFT optimized structures for (a) initial state: adsorbed propyl and hydroxyl radicals with C-O = $0.4 \mathrm{~nm}$, (b) TS: adsorbed propyl and hydroxyl species with $\mathrm{C}-\mathrm{O}=0.215 \mathrm{~nm}$, and (c) adsorbed propanol on a $\mathrm{Ni}(100)$ slab with $\mathrm{C}-\mathrm{O}=0.15 \mathrm{~nm}$.

in Figure 12(a). The central carbon atom of the adsorbed propyl species in Figure 9(a) is on top of one of the $\mathrm{Ni}$ atoms in the $\mathrm{Ni}(100)$ surface. A plane drawn through the three carbon atoms of the propyl radical intersects the surface of the $\mathrm{Ni}(100)$ slab at an angle that is much different than $90^{\circ}$, indicating that the propyl radical is not situated symmetrically on the $\mathrm{Ni}(100)$ surface. The $\mathrm{C}-\mathrm{O}$ bond distance between the central carbon atom in the propyl species and the oxygen atom in the hydroxyl species is $0.4 \mathrm{~nm}$.

The transition state (TS) during the reaction of an adsorbed propyl species and an adsorbed hydroxyl species to form an adsorbed propanol molecule is shown in Figure 12(b). The $\mathrm{C}-\mathrm{O}$ bond distance in the TS has decreased to $0.215 \mathrm{~nm}$ from $0.4 \mathrm{~nm}$ for the $\mathrm{C}-\mathrm{O}$ distance when the two species were in their most stable independent states. It should be noted that both the carbon atom in the propyl species and the oxygen atom in the hydroxyl species are coordinated to the same $\mathrm{Ni}$ atom in the TS, prior to the synthesis reaction and the formation of a $\mathrm{C}-\mathrm{O}$ bond. It appears that they need to be adsorbed on the same atom in order to be geometrically close enough for the bond formation reaction to occur.

The energies of the four species (propyl, hydroxyl, adsorbed propanol, and propanol in the gas phase) are shown in Figure 13, as a function of the $\mathrm{C}-\mathrm{O}$ distance. The energy of reaction from the combination of an adsorbed propyl species plus an adsorbed hydroxyl species to form an adsorbed propanol molecule is $0.507 \mathrm{eV}(48.9 \mathrm{~kJ} / \mathrm{mole})$. The barrier height for formation of propanol from combination of an adsorbed propyl species and an adsorbed hydroxyl species is $1.59 \mathrm{eV}(\sim 153 \mathrm{~kJ} / \mathrm{mole})$. In contrast the barrier height for

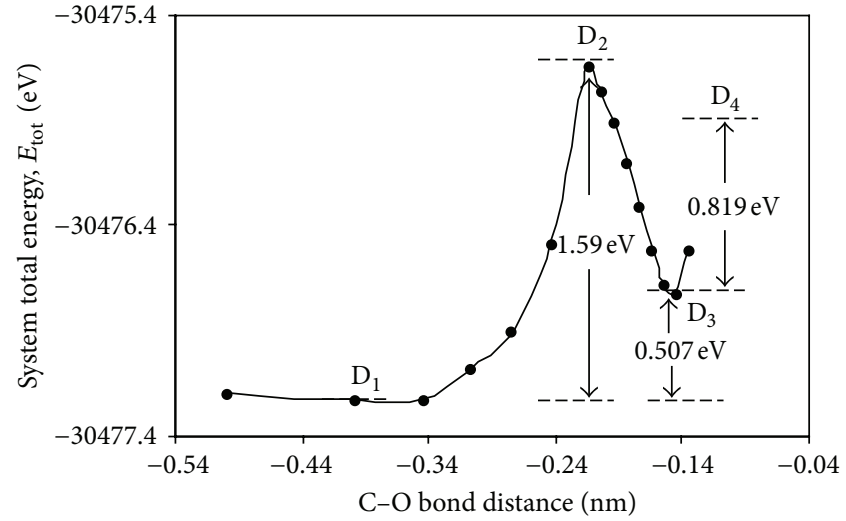

FIGURE 13: Energy plot (obtained using DFT calculated energies) for propanol formation from hydroxyl and propyl species on a $\mathrm{Ni}(100)$ slab. $D_{1}, D_{2}, D_{3}$, and $D_{4}$ are the energy levels for the entities in the reaction sequence shown in Figure 11.

the formation of allyl species $(1.22 \mathrm{eV})$, discussed above, is approximately $25 \%$ less than that of formation of propanol $(1.59 \mathrm{eV})$. Furthermore, to desorb propanol from the $\mathrm{Ni}$ surface into the gas phase, an additional amount of energy $0.819 \mathrm{eV}(\sim 79.0 \mathrm{~J} / \mathrm{mole})$ must be provided.

The Boltzmann factor, $\exp \left(-\Delta E_{\mathrm{TS}} / \mathrm{RT}\right)$, represents the probability that molecules have sufficient energy to attain the transition state, where $\Delta E_{\mathrm{TS}}$ is the barrier height for the reaction. It can be used to estimate the ratio of two reaction rates. The transformation of a propyl species to an allyl species [with 
barrier height $\left.\left(\Delta E_{\mathrm{TS}}\right)^{\text {allyl }}\right]$ is the desired reaction because the species stays on the surface and therefore retains the possibility of eventually being converted to $\mathrm{CO}_{2}$, the complete reaction product. The reaction of a propyl radical with a hydroxyl species to form propanol in the gas phase [with barrier height $\left(\Delta E_{\mathrm{TS}}\right)^{\text {propanol }}$ is the undesired reaction, because propanol is a partially reacted product that retains chemical energy that could have been converted to electrical energy by further reaction to carbon dioxide.

The barrier height for the transformation of adsorbed propyl species to adsorbed allyl species $\left(\Delta E_{\mathrm{TS}}\right)=1.22 \mathrm{eV}$ can be compared with the barrier height for the transformation of the adsorbed propyl species to gas phase propanol. Two reaction steps are used to transform propyl species to gas phase propanol molecules. First, there is the reaction of an adsorbed propyl species with a hydroxyl radical to form adsorbed propanol, $\left(\Delta E_{\mathrm{TS}}\right)^{\text {ads- } \mathrm{C}_{3} \mathrm{H}_{8}}=1.59 \mathrm{eV}$. Then there is the desorption of propanol into the gas phase, $\left(\Delta E_{\mathrm{TS}}\right)^{\text {gas }-\mathrm{C}_{3} \mathrm{H}_{8}}=0.82 \mathrm{eV}$. Because two steps are required for one transformation and one step for the other, a comparison of two different single barrier heights will not describe the phenomenon. The combination $\exp \left[-\left(\Delta E_{\mathrm{TS}}\right)^{\text {propanol }} / \mathrm{RT}\right]=\exp (-1.59 / \mathrm{RT}) * \exp$ $(-0.82 / \mathrm{RT})$ giving $\left(\Delta E_{\mathrm{TS}}\right)^{\text {propanol }}=2.41 \mathrm{eV}$ represents the product of two phenomena.

The ratio of the two reaction rates is

$$
\text { Ratio }=\frac{\text { ally }}{\text { propanol }}=\frac{\exp \left[-\left(\Delta E_{\mathrm{TS}}\right) E^{\text {allyl }} / \mathrm{RT}\right]}{\exp \left[-\left(\Delta E_{\mathrm{TS}}\right)^{\text {propanol }} / \mathrm{RT}\right]} .
$$

The Ratio calculated at $150^{\circ} \mathrm{C}(423 \mathrm{~K})$ was $1.4 * 10^{14}$. That result indicates that propanol is an unlikely product. We are not aware of any experimental fuel cell results on the selectivity for $\mathrm{CO}_{2}$ on a nickel anode. However, platinum is in the same column of the periodic table as nickel, and platinum is frequently used as a fuel cell electrode. These computed results for an $\mathrm{Ni}(100)$ surface are consistent with experimental results on platinum catalysts that found carbon dioxide as the predominant product. This study indicates that carbon dioxide may also be the predominant product on nickel and that the formation of substantial amounts of partially oxygenated products is unlikely.

\section{Conclusion}

The DFT results reported here indicate that the reaction of an adsorbed propyl species to form an adsorbed allyl species on a nickel (100) anode catalyst surface is much more likely than its reaction with a surface hydroxyl species to form gas phase propanol. That suggests that the reaction products from a propane fuel cell having an anode with a nickel electrocatalyst will likely be completely reacted $\left(\mathrm{CO}_{2}\right)$ rather than partially reacted (alcohols, aldehydes, carboxylic acids, and $\mathrm{CO}$ ), thereby converting essentially all the chemical energy in the propane to electrical and thermal energy.

\section{Conflict of Interests}

The authors declare that there is no conflict of interests regarding the publication of this paper.

\section{References}

[1] A. H. Reshak, " $\mathrm{MgH}_{2}$ and $\mathrm{LiH}$ metal hydride crystals as novel hydrogen storage materials," International Journal of Hydrogen Energy, vol. 38, pp. 11946-11954, 2013.

[2] A. Al-Othman, A. Y. Tremblay, W. Pell, S. Letaief, B. A. Peppley, and M. Ternan, "A modified silicic acid $(\mathrm{Si})$ and sulphuric acid (S) -Zrp/PTFE/glycerol composite membrane for high temperature direct hydrocarbon fuel cells," Journal of Power Sources, vol. 224, pp. 158-167, 2013.

[3] A. Al-Othman, A. Y. Tremblay, W. Pell, Y. Liu, B. A. Peppley, and M. Ternan, "The effect of glycerol on the conductivity of Nafion-free ZrP/PTFE composite membrane electrolytes for direct hydrocarbon fuel cells," Journal of Power Sources, vol. 199, pp. 14-21, 2012.

[4] H. A. Liebhafsky and E. J. Cairns, Fuel Cells and Fuel BAtteries: A Guide to Their Research and Development, John Wiley \& Sons, New York, NY, USA, 1968.

[5] J. O. Bockris and S. Srinivasan, Fuel Cells: Their Electrochemistry, McGraw-Hill, New York, NY, USA, 1969.

[6] C. E. Cairns, "Anodic oxidation of hydrocarbons and the hydrocarbon fuel cell," Adv Electrochem and Electrochem Eng, vol. 8, pp. 337-392, 1971.

[7] M. D. Gross, J. M. Vohs, and R. J. Gorte, "Recent progress in SOFC anodes for direct utilization of hydrocarbons," Journal of Materials Chemistry, vol. 17, no. 30, pp. 3071-3077, 2007.

[8] P. Heo, K. Ito, A. Tomita, and T. Hibino, "A proton-conducting fuel cell operating with hydrocarbon fuels," Angewandte Chemie, vol. 47, no. 41, pp. 7841-7844, 2008.

[9] S. Y. Hsieh and K. M. Chen, "Anodic oxidation of methane," Journal of the Electrochemical Society, vol. 124, no. 8, pp. 11711174, 1977.

[10] M. G. Sustersic, R. Cordova, W. E. Triaca, and A. J. Arvia, "Electrosorption of methane and its potentiodynamic electrooxidation on platinized platinum," Journal of the Electrochemical Society, vol. 127, no. 6, pp. 1242-1248, 1980.

[11] F. Hahn and C. A. Melendres, "Anodic oxidation of methane at noble metal electrodes: an "in situ" surface enhanced infrared spectroelectrochemical study," Electrochimica Acta, vol. 46, no. 23, pp. 3525-3534, 2001.

[12] O. Savadogo and F. J. Rodriguez Varela, "Low-temperature direct propane polymer electrolyte membranes fuel cell (DPFC)," Journal of New Materials for Electrochemical Systems, vol. 4, no. 2, pp. 93-97, 2001.

[13] C. K. Cheng, J. L. Luo, K. T. Chuang, and A. R. Sanger, "Propane fuel cells using phosphoric-acid-doped polybenzimidazole membranes," Journal of Physical Chemistry B, vol. 109, no. 26, pp. 13036-13042, 2005.

[14] F. J. R. Varela and O. Savadogo, "The effect of anode catalysts on the behavior of low temperature Direct Propane Polymer Electrolyte Fuel Cells (DPFC)," Journal of New Materials for Electrochemical Systems, vol. 9, no. 2, pp. 127-137, 2006.

[15] F. T. Bacon and T. M. Fry, “The development and practical application of fuel cells," Proceedings of the Royal Society A, vol. 334, pp. 427-452, 1973. 
[16] V. S. Bagotzky, Y. B. Vassiliev, and O. A. Khazova, “Generalized scheme of chemisorption, electrooxidation and electroreduction of simple organic compounds on platinum group metals," Journal of Electroanalytical Chemistry, vol. 81, no. 2, pp. 229238, 1977.

[17] H. Wroblowa, B. J. Piersma, and J. O. Bockris, "Studies of the mechanism of the anodic oxidation of ethylene in acid and alkaline media," Journal of Electroanalytical Chemistry, vol. 6, no. 5, pp. 401-416, 1963.

[18] W. T. Grubb and C. J. Michalske, "A high performance propane fuel cell operating in the temperature range of $150-200^{\circ} \mathrm{C}$," Journal of the Electrochemical Society, vol. 111, pp. 1015-1019, 1964.

[19] S. Bertholet, E. Gehain, F. Hahn, J. M. Leger, S. Srinivasan, and C. Lamy, "Electrooxidation of methane: PEMFC and in situ electrochemical spectroscopic studies," in Proceedings of the Meeting Abstracts- Electrochemical Society, vol. 98 of Abstract No. 1D90, Boston, Mass, USA, 1998.

[20] F. J. Rodríguez Varela and O. Savadogo, "Real-time mass spectrometric analysis of the anode exhaust gases of a direct propane fuel cell," Journal of the Electrochemical Society, vol. 152, no. 9, pp. A1755-A1762, 2005.

[21] J. M. Soler, E. Artacho, J. D. Gale et al., "The SIESTA method for ab initio order-N materials simulation," Journal of Physics Condensed Matter, vol. 14, no. 11, pp. 2745-2779, 2002.

[22] J. P. Perdew, K. Burke, and M. Ernzerhof, "Generalized gradient approximation made simple," Physical Review Letters, vol. 77, no. 18, pp. 3865-3868, 1996.

[23] W. M. Haynes, CRC Handbook of Chemistry and Physics, CRC Press, 91st edition, 2010.

[24] J. P. Perdew, A. Ruzsinszky, G. I. Csonka et al., "Restoring the density-gradient expansion for exchange in solids and surfaces," Physical Review Letters, vol. 100, Article ID 136406, 2008.

[25] D. C. Ford, A. U. Nilekar, Y. Xu, and M. Mavrikakis, "Partial and complete reduction of $\mathrm{O}_{2}$ by hydrogen on transition metal surfaces," Surface Science, vol. 604, no. 19-20, pp. 1565-1575, 2010.

[26] T. Jiang, D. J. Mowbray, S. Dobrin et al., "Trends in CO oxidation rates for metal nanoparticles and close-packed, stepped, and kinked surfaces," Journal of Physical Chemistry C, vol. 113, no. 24, pp. 10548-10553, 2009.

[27] J. S. Hummelshøj, J. Blomqvist, S. Datta et al., "Communications: elementary oxygen electrode reactions in the aprotic Liair battery," Journal of Chemical Physics, vol. 132, no. 7, Article ID 071101, 2010.

[28] C. D. Taylor, M. Neurock, and J. R. Scully, "A first-principles model for hydrogen uptake promoted by sulfur on Ni(111)," Journal of the Electrochemical Society, vol. 158, no. 3, pp. F36-F44, 2011.

[29] L. C. Grabow, B. Hvolbæk, and J. K. Nørskov, “Understanding trends in catalytic activity: the effect of adsorbate-adsorbate interactions for Co oxidation over transition metals," Topics in Catalysis, vol. 53, no. 5-6, pp. 298-310, 2010.

[30] L. Nykänen and K. Honkala, "Density functional theory study on propane and propene adsorption on $\mathrm{Pt}(111)$ and $\mathrm{PtSn}$ alloy surfaces," Journal of Physical Chemistry C, vol. 115, no. 19, pp. 9578-9586, 2011

[31] A. Antony, C. Hakanoglu, A. Asthagiri, and J. F. Weaver, "Dispersion-corrected density functional theory calculations of the molecular binding of n-alkanes on $\mathrm{Pd}(111)$ and $\mathrm{PdO}(101)$, Journal of Chemical Physics, vol. 136, no. 5, Article ID 054702, 2012.
[32] C.-L. Kao and R. J. Madix, “The adsorption dynamics of molecular methane, propane, and neopentane on $\operatorname{Pd}(111)$ : theory and experiment," Journal of Physical Chemistry B, vol. 106, no. 33, pp. 8248-8257, 2002.

[33] M. Smutek and S. Černý, "Calorimetric studies of hydrocarbon adsorption on metal films. III. Methane, ethane and propane on molybdenum," Journal of Catalysis, vol. 47, no. 2, pp. 178-189, 1977.

[34] J. Kua and W. A. Goddard III, "Oxidation of methanol on $2^{\text {nd }}$ and $3^{\text {rd }}$ row group VIII transition metals (Pt, Ir, Os, $\mathrm{Pd}, \mathrm{Rh}$, and $\mathrm{Ru}$ ): application to direct methanol fuel cells," Journal of the American Chemical Society, vol. 121, no. 47, pp. 10928-10941, 1999.

[35] M. Pozzo, G. Carlini, R. Rosei, and D. Alfe, "Comparative study of water dissociation on $\mathrm{Rh}(111)$ and $\mathrm{Ni}(111)$ studied with first principles calculations," Journal of Chemical Physics, vol. 126, no. 16, Article ID 164706, 2007. 


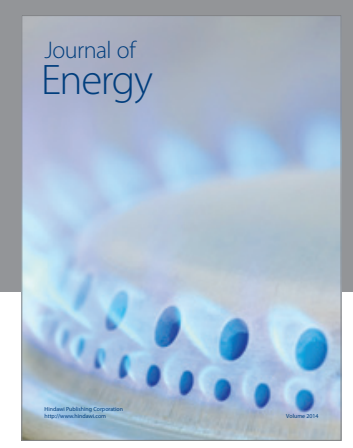

Journal of

Industrial Engineering
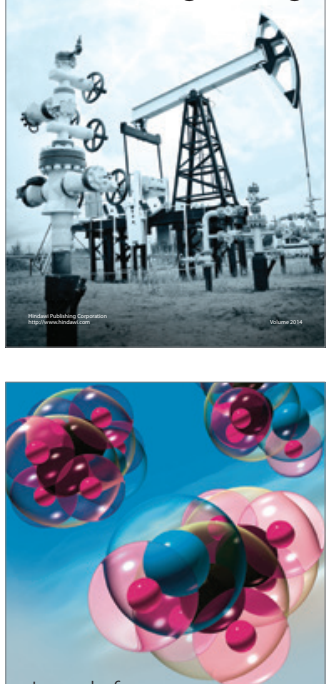

Fuels
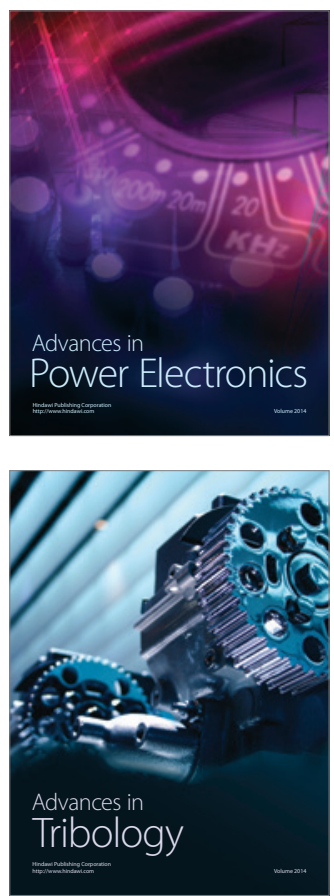

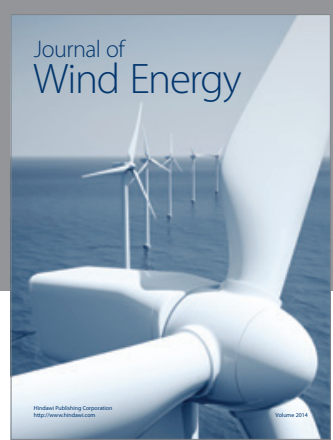

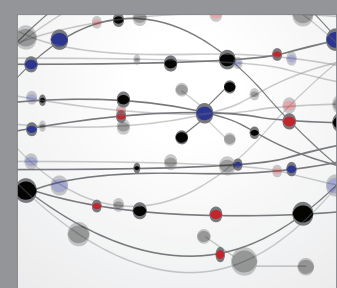

The Scientific World Journal

Submit your manuscripts at http://www.hindawi.com

Journal of

Structures
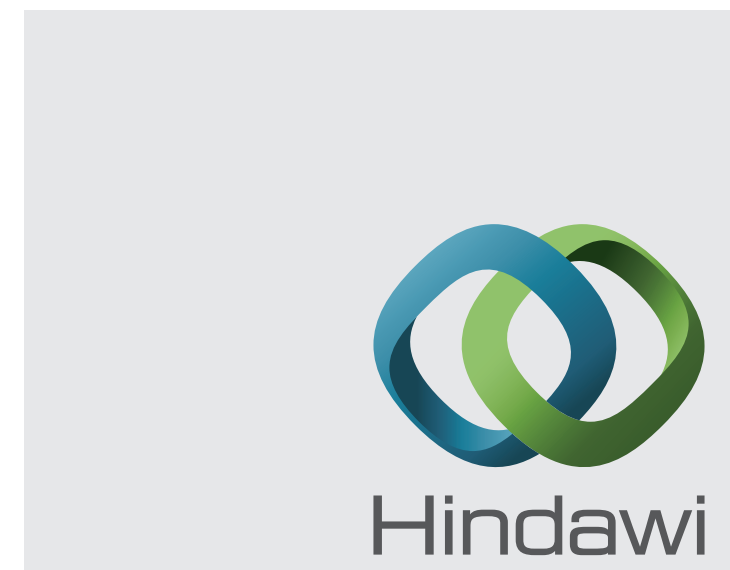

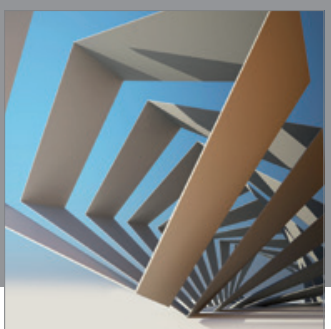

Rotating

Machinery
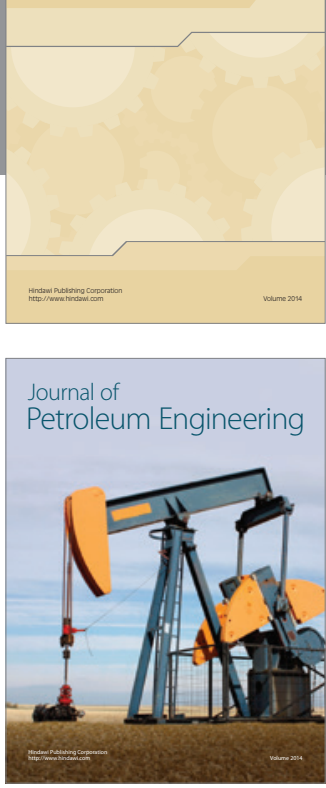

Journal of

Solar Energy
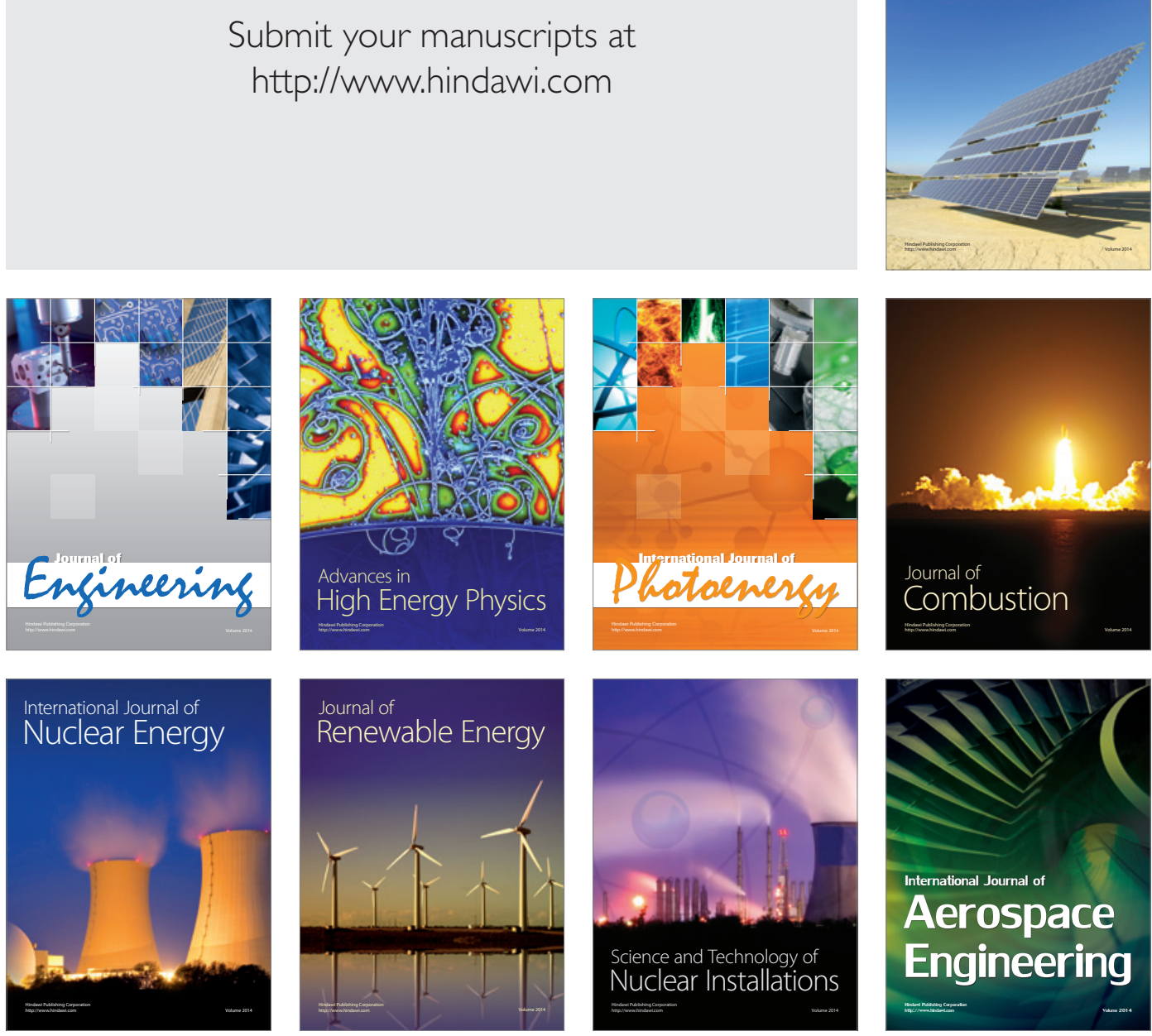